Available online at GSC Online Press Directory

GSC Biological and Pharmaceutical Sciences

e-ISSN: 2581-3250, CODEN (USA): GBPSC2

Journal homepage: https://www.gsconlinepress.com/journals/gscbps

(RESEARCH ARTICLE)

\title{
Pollinosis caused by the representatives of Gramineae family
}

\author{
Kallajxhiu Nikoleta ${ }^{1,}{ }^{*}$, Kapidani Gëzim ${ }^{2}$ and Turku Silvana ${ }^{1}$ \\ ${ }^{1}$ Department of Biology, FNS, University of Elbasan "Aleksandër Xhuvani", Elbasan, Albania. \\ ${ }^{2}$ Department of Biology, FNS, University of Tirana, Tirana, Albania.
}

Publication history: Received on 20 May 2020; revised on 28 May 2020; accepted on 29 May 2020

Article DOI: https://doi.org/10.30574/gscbps.2020.11.2.0148

\begin{abstract}
There are a large variety of plants belonging to different families in the Elbasan region, Albania. Some of them are of a high medicinal value, some are honey plants and some others are nutritive, forage and spontaneous. An important place in this variety of plants take the one with allergic pollen which cause irritation of airways in persons who are susceptible to allergic factor, including representatives of the Gramineae family. In this study are featured the allergic cases of 251 patients for the period from January 2018 to December 2019. Results were obtained after allergy trials with 8 herbal allergens of the Gramineae family [Avena sativa (oat), Cynodon dactylon (bermuda grass), Dactylis glomerata (cock'sfoot), Hordeum vulgare (barley), Phleum pratense (timothy grass), Poa pratensis (meadow-grass), Secale cereale (rye) and Triticum aestivum (wheat)]. The study found that in 72 patients, Phleum pratense pollen is the main cause for allergic disease; the most affected age group by pollen grains of Gramineae family is 21 to 30 years, the male gender is most affected by pollinosis and allergic diseases are encountered most in urban areas, with 141 cases. The study was accompanied by photos of the plants in the habitat where they were found, by photos of pollen grains as well as graphs showing the variability of allergic morbidity between age groups and gender.
\end{abstract}

Keywords: Elbasan; Allergic pollen; Gramineae family; Variability of diseases

\section{Introduction}

Pollen grains such as aeroallergens have been well studied around the world and are an important cause of allergic diseases. The presence and concentration of pollen in the atmosphere depends on the type of species that produces it, on various climatic factors such as temperature, humidity, wind direction, good or bad weather, precipitation, tobacco smoke, presence of nitrogen dioxide $\left(\mathrm{NO}_{2}\right)$, sulfur dioxide $\left(\mathrm{SO}_{2}\right)$, ozone $\left(\mathrm{O}_{3}\right)$, diesel particles and other seasonal factors. Due to clime changes, the study of variations in daily and seasonal of the prevalence becomes very important. Many studies show that representatives of the Gramineae family are among the leading causes of various allergic diseases [1, $2,3,4,5,6,7,8]$.

The development of civilization which leads to environment pollution and overcrowding of urban areas often, stimulates the sharp increase in the number of people affected by allergic diseases. In a study in 12 countries it was noticed that in a large number of individuals aged 22 to 44 years, specific IgE levels to Phleum pratense ranged from $3.8 \%$ in Ireland to $15.6 \%$ in Switzerland were detected [9]. An interesting study which included 1456 subjects, in the Isle of Wight (UK) from 1989 to 1990 the children were submitted to skin prick tests at the age of 4 years [10].

Sensitivity to allergic pollens was demonstrated in 1101 random children aged 8 to 11 years from Freiburg school (Germany). 19.7\% were sensitive and the allergic rhinitis diagnosis was present in $8.7 \%$ of the sample [11]. A study performed in adults living in Wien (Austria), submitted that 17\% of healthy inviduals were sensitized to grass [12]. From the study undertaken for the period 2004 to 2008, measuring the prevalence of allergic diseases in the Elbasan

\footnotetext{
${ }^{*}$ Corresponding author: Kallajxhiu Nikoleta
} 
region (Albania), it was found that 80 cases of allergic diseases were caused by pollen of representatives of Gramineae family [6].

It is extremely important to investigate the link between allergic diseases and heredity. From a 1978 Italy research of a population of outpatients, a figure of about $45 \%$ was found to be related to familiarity. Much has been discussed about the impact of allergies on different gender. Recent work shows that male gender is the most affected one by bronchial asthma in the first few years of life with a 2:1 ratio, whereas in terms of allergic rhinitis there seems to be no significant difference between the two genders $[13,14,15,16,17]$. From the analysis of allergy cases in the Elbasan region (Albania) for the years 2004-2008, males were more affected than females [18] and for the period from January 2018 to June 2019, 217 allergic patients were males and 157 were females [7].

The Gramineae family is a large and nearly ubiquitous family of monocotyledonous plants. Representatives of the Gramineae family are herbaceous plants one or more years old. In the Albanian flora there are approximately 93 genera, with 240 plant species. They are anemophilous plants and produce a greater amount of pollen than entomophilous ones. Pollen grains can spread over great distances. They are widespread in many habitats. The flowers are not glowing and non-aromatic to attract pollinators. In general, these plants flower from March-April to the end of the summer, JulyAugust [19]. Accurate identification of the plant causing allergies has a major preventive effect on allergic diseases. By knowing the plant, the patient is informed of the flowering period and its pollination and in this way he knows how to manage the exposure to pollen as more effective as possible [20]. Pollen grains of Gramineae family are monoporate. Their shape varies from spheroid to oblate spheroid and the dimensions can be medium or large. The layer of exine is mainly granular $[6,21,22]$.

\section{Material and methods}

\subsection{Determination of allergic herbs}

To conduct the study, field expeditions were undertaken to find plants whose pollens were used as allergens in the performing of allergy tests.Determination of the plants is made by the flora of Albania [19]. Laboratory processing of pollen grains was carried out using two analytical methods, the acetolysis method according to Erdtman and the one with basic fuchsine according to Smoljaninova \& Gollubkova [23, 24]. Micrographs of pollen grains in polar and equatorial views were presented with magnification of 400x and 1000x, taken by the Biological Microscope (Motic BA310 Series LED-Digital).

\subsection{Determination of allergic disease}

To accomplish one of the goals of the study, the evidence of pollen allergic patients for the period January 2018December 2019, obtained in a biochemical laboratory, was studied. There were about 251 patients. Allergy Euroline Mediterranean Inhalation test was used to determine the pollen allergy and 8 different plant allergens of the Gramineae family were used.

To see the variability of the disease, age, gender, place of residence and type of plant causing the allergy were taken into consideration for each patient. To determine accurately the cause of allergy, measurements of the concentration of antibodies were done throughout the test. Concentration of antibodies was calculated according to 6 classes. Table 1 shows in detail the concentration of immunoglobulin E (IgE) in blood for each class, in kilo unit per liter (kU/l) measurement.

Table 1 Concentration of antibodies in $\mathrm{kU} / \mathrm{l}$

\begin{tabular}{lll}
\hline Nr. & Concentration (kU/l) & Explanation \\
\hline $\mathbf{0}$ & $<0,35 \mathrm{kU} / \mathrm{l}$ & No specific antibody detection \\
$\mathbf{1}$ & $0,35 \mathrm{kU} / \mathrm{l}-0,7 \mathrm{kU} / \mathrm{l}$ & Very weak antibody \\
$\mathbf{2}$ & $0,7 \mathrm{kU} / \mathrm{l}-3,5 \mathrm{kU} / \mathrm{l}$ & Weak antibody concentration \\
$\mathbf{3}$ & $3,5 \mathrm{kU} / \mathrm{l}-17,5 \mathrm{kU} / \mathrm{l}$ & Clear antibody detection, clinical evidence is mostly present \\
$\mathbf{4}$ & $17,5 \mathrm{kU} / \mathrm{l}-50 \mathrm{kU} / \mathrm{l}$ & Strong antibody concentration \\
$\mathbf{5}$ & $50 \mathrm{kU} / \mathrm{l}-100 \mathrm{kU} / \mathrm{l}$ & Very strong antibody concentration \\
$\mathbf{6}$ & $>100 \mathrm{kU} / \mathrm{l}$ & Extremely high antibody concentration \\
\hline
\end{tabular}




\section{Results and discussion}

The following table shows the list of allergens of the Gramineae family used to perform allergy tests. Eight herbal allergens of this family have been used. For each of them is determined the flowering period. The following pictures show photos of plants in their habitat and microscopic photos of some of their pollen (Figure 1 and Figure 2).

Table 2 List of allergic pollen grains of Gramineae family

\begin{tabular}{lll}
\hline Nr. & The name of allergen & Flowering period \\
\hline 1. & Avena sativa & may-june \\
2. & Cynodon dactylon & may-october \\
3. & Dactylis glomerata & may-july \\
4. & Hordeum vulgare & june-july \\
5. & Phleum pretense & april-november \\
6. & Poa pratensis & may-september \\
7. & Secale cereale & may-july \\
8. & Triticum aestivum & june-july \\
\hline
\end{tabular}

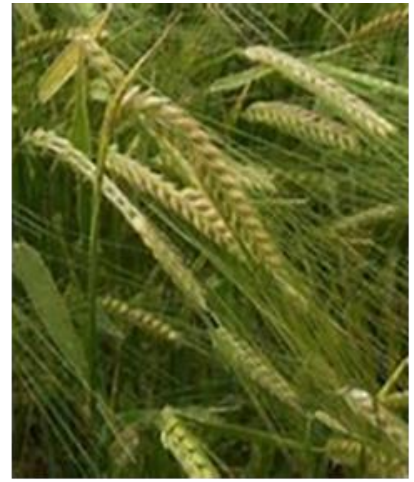

Hordeum vulgare

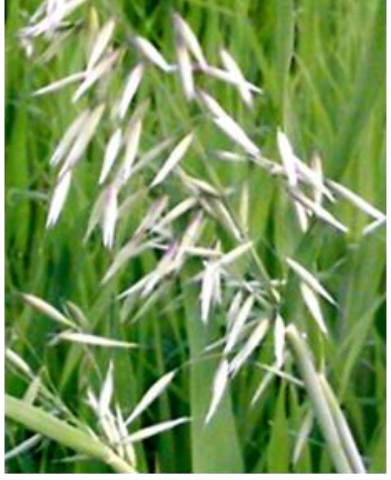

Avena sativa

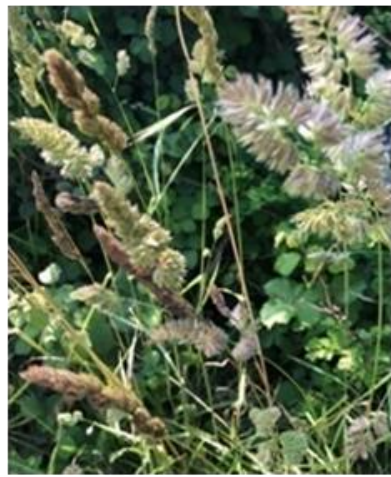

Dactylis glomerata

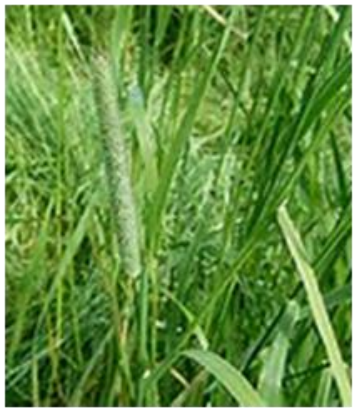

Phleum pretense

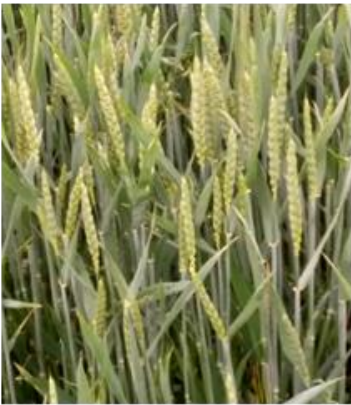

Triticum aestivum

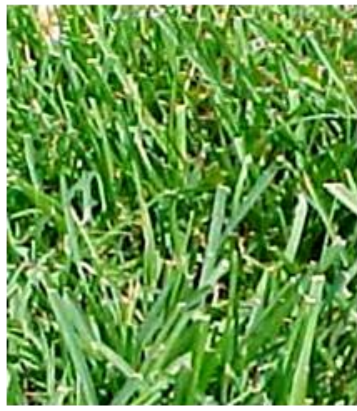

Poa pratensis

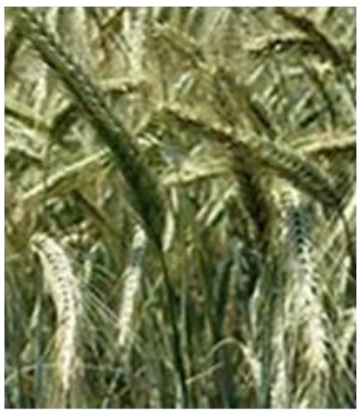

Secale cereale

Figure 1 Photos of plants in their habitat 


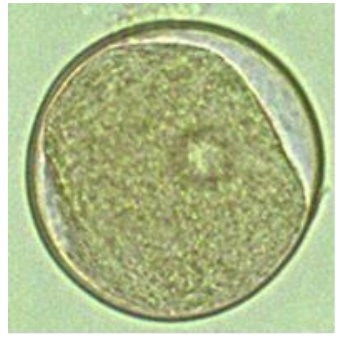

a

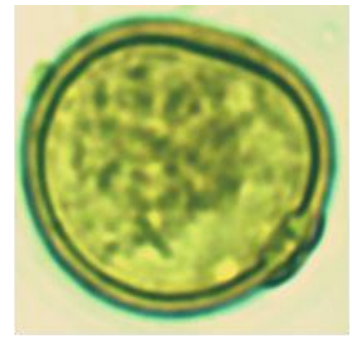

b

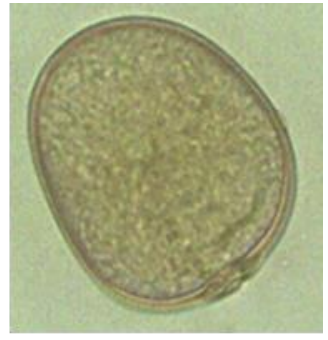

C

Figure 2 Photos of pollen grains. a. polar view, acetolysed in Triticum aestivum; b. Equatorial view, acetolysed in Cynodon dactyon; c. Equatorial view, acetolysed in Avena sativa (Obtained at 1000x magnification (a, b) and 400x magnification (c). photos: Kallajxhiu N.)

The results obtained after the test are presented in Table 3.

Table 3 Data for allergic patients from pollen grains (Gramineae)

\begin{tabular}{llllc}
\hline Nr. & The name of allergen & 2018 year & 2019 year & Number of patients \\
\hline 1. & Avena sativa & 10 & 15 & 25 \\
2. & Cynodon dactylon & 17 & 18 & 35 \\
3. & Dactylis glomerata & 10 & 12 & 22 \\
4. & Hordeum vulgare & 5 & 4 & 9 \\
5. & Phleum pratense & 20 & 52 & 72 \\
6. & Poa pratensis & 15 & 21 & 36 \\
7. & Secale cereale & 20 & 14 & 34 \\
8. & Triticum aestivum & 8 & 10 & 18 \\
& Totally & 105 & 146 & 251 \\
\hline
\end{tabular}

It is clear from the table that allergy tests were done by 251 patients. In the period January 2018 - December 2018,105 patients underwent allergy tests, while during 2019 about 146 patients, making a sum of 251 patients in total. The figures of the table show that for this period, the highest number of allergy cases was reached by the Phleum pretense, with 72 cases. It is followed by Poa pratensis, with 39 cases and so on. The results also match those of the literature [6, $7,8,13,18,25]$. The lowest number of cases of our patients was caused by the Hordeum vulgare pollen, with only 8 cases.

\subsection{Variability of allergic cases}

It is well known that high susceptibility to allergic factor varies by age, gender and place of residence. From the data obtained during the study, it has been noticed that this claim applies also to our patients. Based on the following graph, we are presenting the variability of pollen allergic disease between different age groups. 


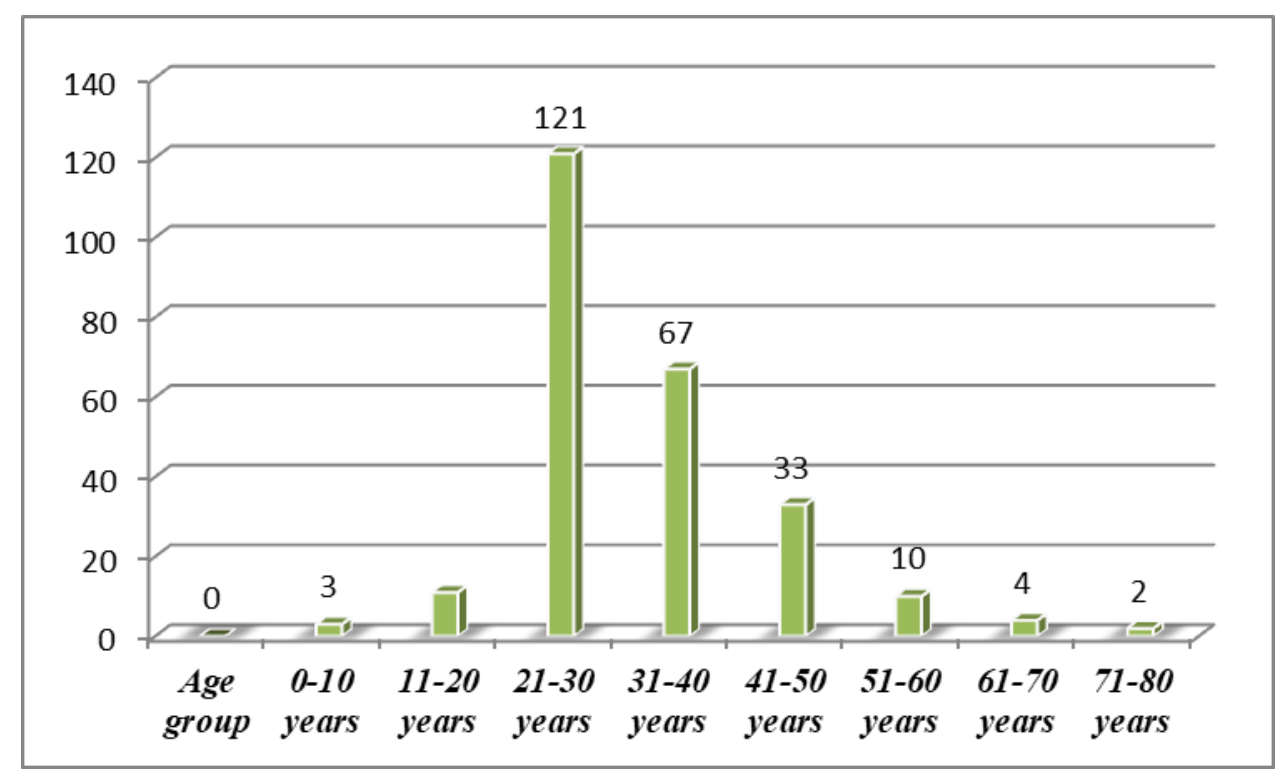

Figure 3 Variability of allergy by age group for two years

Based on the data of figure 3, it is clear that the most affected age group by Gramineae family's pollen allergy is 21-30 years. In my opinion, this is because it is the most active age of society, thus it is more in contact with the pollen of the allergic plants. Also, it is an age group, where the chance of developing a nicotine addiction is higher than in the other age groups. Cigarette users are known to be more susceptible to allergic diseases.

Allergic diseases from pollen also vary by place of residence. The literature shows that people living in the urban area are more sensitive to allergies. This is because these areas have a greater pollution than rural areas [26]. This pollution, in the first place, is caused by the large use of automobiles and by the industrial development in Elbasan. As a result, many harmful gases such as nitrogen dioxide $\left(\mathrm{NO}_{2}\right)$, sulfur dioxide $\left(\mathrm{SO}_{2}\right)$, ozone $\left(\mathrm{O}_{3}\right)$ and diesel particles are released into the atmosphere. As Figure 4 shows, in populated areas, about 141 patients have been affected by allergic diseases caused by pollen grains, compared to 110 spotted in rural areas.

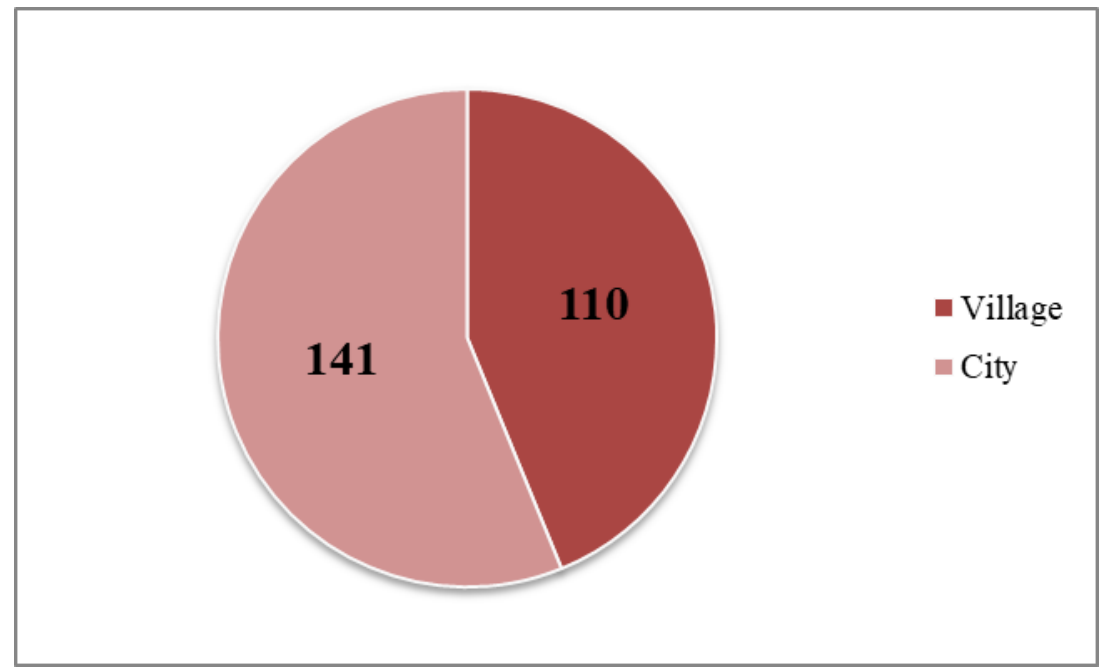

Figure 4 Variability of diseases by place of residence

According to the results obtained from the allergy tests in a private laboratory in the region of Elbasan, it resulted that for the period of 2 years January 2018-December 2019, the male sex is more affected by pollinosis. Specifically, about $64 \%$ of the affected population were male and $36 \%$ are of the opposite sex. The data is clearly shown in the figure below. 


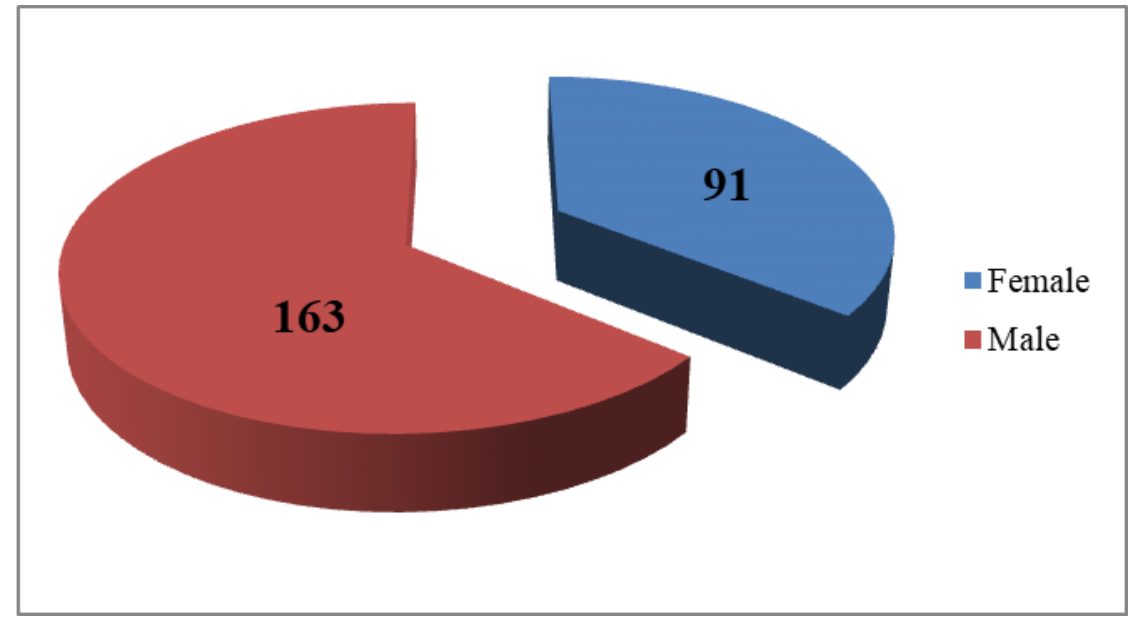

Figure 5 Variability of diseases by gender

\section{Conclusion}

The study found that representatives of the Gramineae family are among the leading causes of allergic diseases caused by their pollen. Phleum pretense pollen grains (timothy grain pollen) have caused the highest number of allergic cases with about 72 cases, followed by Poa pratensis (meadow grass) with 36 cases and so on. The most affected age group by this allergy was 21-30 years old and the most common gender was male, with 163 patients. Allergic disease has mostly affected the inhabitants of the urban areas, with 141 patients compared to 110 patients found in the rural areas.

\section{Compliance with ethical standards}

\section{Acknowledgments}

We want to thank all the allergists of the laboratories where we worked to determine the allergic cases from the Gramineae family.

\section{Disclosure of conflict of interest}

All authors declare that they have no conflict of interest.

\section{References}

[1] Chanda S. (1973). Atmospheric pollen flora of Greater Calcutta and Falta. Asp Allergy Appl Immunol, 6, 74-81.

[2] Chen K, Liao YF and Zhang JT. (1988). The major aeroallergens in Guangxi, China. Clin Allergy,18, 589-596.

[3] Satheesh R, Rao GR and Nair PK. (1992). The airborne pollen incidence in relation to season and vegetation at Kodaikanal. Indian J Aerobiol, 37-42.

[4] Jose C, Prieto-Baena, Pablo JH, Dominiquez E and Galan C. (2003). Pollen production in the Poaceae family, Grana, $42,153-160$.

[5] Damialis A and Konstantinou GN. (2011). Cereal pollen sensitisation in pollen allergic patients: to treat or not to treat? Eur Ann Allergy ClinImmunol, 43(2), 3-44.

[6] Kallajxhiu N. (2011). Studimi alergopalinologjik i bimëve alergjike të rrethit të Elbasanit dhe i alergjive të shkaktuara prej tyre (Monografi), Rama Graf, Elbasan, 1-106.

[7] Kallajxhiu N, Kapidani G, Turku S and Dauti A. (2019). Variability of allergic diseases from pollen grains in the Elbasan region, Albania. European Academic Research, Vol. VII, Issue 5, 284-285.

[8] Kallajxhiu N, Kapidani G, Turku S and Dauti A. (2019). Influence of pollen grains in allergic diseases. Int. J., Curr. Microbiol. App. Sci, 8(3), 787-796. 
[9] Chinn S, Burney P, Sunyer J, Jarvis D andLuczynska C. (1999). Sensitization to individual allergens and bronchial responsiveness in the ECRHS. EurRespir J, 14, 876-84.

[10] Tariq SM, Matthews S and Hakim E. (2001). Sensitization to common allergens and its association with allergic disorders at age 4 years: a whole population birth cohort study. Pediatrics, 108, E33.

[11] Riedinger F, Kuehr J, Strauch E, Schulz H, Ihorst G and Forster J. (2002). Natural history of hay fever and pollen sensitization, and doctor's diagnosis of hay fever and pollen asthma in German schoolchildren. Allergy, 57, 48892.

[12] Zwick H, Popp W, Jager S, Wagner C, Reiser KandHorak F. (1991). Pollen sensitization and allergy in children depend on the pollen load. Allergy, 46, 362-366.

[13] Bottelli R, Falagiani P, Galimberti M, Lenzi G, Pacini EandRolo J. (1982). I pollini e la Pollinsi, Publ. Piccin Editore Padova-Nuova Libraria, 10-13, 15-20.

[14] Croner S. (1992). Prediction and detection of allergy development: influence of genetic and environmental factors, J. Pediatr, 121 (5Pt 2), 58-63.

[15] Stach A. (1995). Pollen fall of certain allergenic plants in Poznan in the years surrounding area (Poland), 27-28.

[16] D’Amato G, Spieksma FThM, Liccardi G, Ja“ger S, Russo M, Kontou-Fili K, Nikkels H, Wüthrich B and Bonini S. (1998). Pollen-related allergy in Europe. - Allergy, 53, 567-578.

[17] Sener O, Kim YK, Ceylan S, Ozanguc N and Yoo TJ. (2003). Comparison of skin tests to aeroallergens in Ankara and Seoul. J Investig Allergol Clin Immunol., 13, 202-208.

[18] Kallajxhiu N. (2010). Studimi alergopalinologjik I bimëve alergjike të rrethit të Elbasanit dhe i alergjive të shkaktuara prej tyre. Ph.D. thesis, University of Tirana, Albania, 95-107.

[19] Vangjeli J, Ruçi B, Mullaj A, Paparisto K and Qosja Xh. (2000). Flora e Shqipërisë, Vëllimi IV, Tiranë.

[20] Subba-Reddi C and Reddi NS. (1986). Pollen production in some anemophilous angiosperms. Grana, 25, 55-61.

[21] Kapidani G. (2004). Fjalori i palinologjisë, Shtypshkronja “Sejko”, Elbasan, 1-149.

[22] Lekli L, Mersinllari M, Qirko E, Xhixha F and Hoxha M. (2008). Bimët alergjike në Shqipëri. Presso arti grafiche favia S. R. L., Modugno (Ba), 1-299.

[23] Smolianinova LA and Gollubkova VF. (1953). L.A.K. Metodike issledovania pilci. Dok. Ak. Nauk. SSSR T. LXXXVIII. N 1, 125-126.

[24] Erdtman G. (1956). Morfologija pilci i sisitematika rastenij, Angiosperma. Moskva, 12-14, 25-85.

[25] Gala'n C, Emberlin J, Domı́nguez E, Bryant RH and Villamandos F. (1995). A comparative analysis of daily variations in the Gramineae pollen counts at Co'rdoba, Spain and London, UK. Grana, 34, 189-198.

[26] Ducker CS and Knox BR. (1985). Pollen and people. Biotechnlogy and ecology of Pollen. New-York, 399-404.

\section{How to cite this article}

Kallajxhiu N, Kapidani G and Turku S. (2020). Pollinosis caused by the representatives of Gramineae family. GSC Biological and Pharmaceutical Sciences, 11(2), 334-340. 